\title{
How Ground Improvement Addresses the United Nation Sustainable Development Goals: A Review
}

\author{
Mahdi Keramatikerman, Amin Chegenizadeh* and Hamid Nikraz \\ Department of Civil Engineering, Curtin University of Technology, Australia
}

*Corresponding author: Amin Chegenizadeh, Department of Civil Engineering, Curtin University of Technology, Australia.

\begin{abstract}
The sustainable development goals (SDGs) were agreed by 195 nations on United Nation (UN) climate change conference in Paris 2015. The agreement was about climate actions to reduce the global warming and reinforcing countries strengths in dealing with climate change phenomenon by means of 17 goals. Researchers and engineers can have a significant contribution in successfulness of the Paris agreement. In particular, ground improvement in geotechnical engineering can have an effective role in promoting goal 12 of the UN SDGs to ensure sustainable consumption and production pattern. One of the key targets for this goal is substantially reduction of the waste production by means of recycling and reuse by 2030 . Given the increasing trend of the world's population, as such, the production and consumption rates have an increasing trend which makes achieving this goal so challenging. Some manufacturing industries generate by-products in addition to their end-products that usually dump in landfills or occasionally reuse. Many of these by-products have a pozzolanic characteristics that can be used in combination with cement or lime. The materials such as fly ash (FA), blast furnace slag (BFS) are some of these materials. This mini review highlights application of some of these by products in tackling goal 12 of the United Nation sustainable development goals.
\end{abstract}

Keywords: UNSDGs; Goal 12; By products; Reuse; Ground improvements

\section{Introduction}

Goal 12 in United Nation sustainable development goals (UNSDGs) clearly has putin place an ambitious target to significantly reduce generation of the waste by reusing and or recycling by 2030. Application of waste material in improvement of the soil behaviour has been investigated since many years ago [1-5]. The blast furnace slag (BFS), fibre, tyre, and fly ash (FA), sawdust is some of by product that remain from different manufacturing industries and have successfully been utilized in ground improvement studies [612]. As an example, fly ash (FA) is remained from burning coals in electrical power plants. This by product has a strong pozzolanic characteristics that can be mixed with Portland cement (PC) and lime to increase soil strength during the time. For instance, Fernández-Pereira [13] investigated effect of addition of fly ash in improvement of the brick strength and reported that addition of up to $20 \%$ fly ash in production of brick is effective to improve strength of the bricks made from clay. Similar results were reported by Olgun $[14,15]$ amongst others.
Blast furnace slag (BFS) is another example of the by-products that remains from steel manufacturing industry. For instance, Cokca [16] investigated effect of two types of slags in reducing swelling behaviour of clay and indicated they can be utilized successfully if use in percentages of $5 \%$ to $25 \%$. In a similar study, Yi [17]. compared two types of slag when mixed with cement and clay on stabilization of the soil. They indicated that generation of hydration products promoted by addition of slag and this enhanced soil strength. Similar results were reported by Kukko [18]. Now adays, a huge number of tyres are dumping in landfills. Dumping tyres in landfills may be along with generation of hazardous leachate during the time. Previous ground improvement studies also have shown an effective usage of recycled tyres in crumbed, shredded, and powdered forms. As an example, Cabalar [19] investigated effect of addition of buffing tyre and lime in clay stabilization. They used California bearing ratio (CBR) testing and indicated that addition of tyre mixed with lime can be helpful in reducing pavement thickness 
as this enhances the CBR value. Similarly, Pelisser [13] investigated geotechnical characteristics of the recycled tyre (as a replacement for sand) admixed with PC helps in production of the lightweight concrete with lesser cement that has an acceptable compressive strength. Similar results were reported by Shibi \& Kamei [20]. Textile and fibre industry are another industry that produces a significant amount of waste every year. Ground improvement researchers have successfully utilized fibre in improvement of the soil behaviour. For instance, Fatahi [21] investigated effect of fibre addition shear strength of cemented clay and indicated that this is effective to enhance these characteristics of soil. Similar studies performed by [15,22-24] similar results were reported.

\section{Conclusion}

The defined 17 United Nation sustainable development goals are a framework is a climate action to address the global warming phenomenon. The goal 12 clearly indicates that generation of the waste should significantly be reduced by reusing and recycling of the waste by 2030 . To address this global target, ground improvement projects can have a substantial contribution by finding innovative and by-products material that can be mixed along with traditional stabilizers such as Portland cement (PC) and lime in improvement of soil. This helps reduction of the production of these expensive agents as well as reuse of waste materials and helping to reduce global warming issue. This study highlighted application of some of the most used by-product in ground improvement studies. The byproducts such as fly ash, blast furnace slag, tyre, sawdust, and fibre are some of the most useful by-products that successfully have been used in ground improvement projects.

\section{Acknowledgement}

None.

\section{Conflict of Interest}

No conflict of interest.

\section{References}

1. Chegenizadeh A, Nikraz H (2011a) Composite soil: Fiber inclusion and strength. Advanced Materials Research pp. 1646-1650.

2. Chegenizadeh A, Nikraz H (2011b) Study on modulus of elasticity of reinforced clay. Advanced Materials Research pp. 5885-5889.

3. Chegenizadeh A, Nikraz H (2011c) Investigation on compaction characteristics of reinforced soil. Advanced Materials Research pp. 964968.

4. Chegenizadeh A, Nikraz H (2011d) Investigation on strength of fiber reinforced clay. Advanced Materials Research pp. 957-963.

5. Chegenizadeh A, Nikraz H (2011e) Composite Clayey Sand and Short Fiber. Advanced Materials Research pp. 2764-2769.

6. Chegenizadeh A, Keramatikerman M, Nikraz H (2018a) Liquefaction resistance of fibre reinforced low-plasticity silt. Soil Dynamics and Earthquake Engineering 104: 372-377.
7. Chegenizadeh A, Keramatikerman M, Dalla Santa G, Nikraz H (2018b) Influence of recycled tyre amendment on the mechanical behaviour of soil-bentonite cut-off walls. Journal of cleaner production 177: 507-515.

8. Chegenizadeh A, Keramatikerman M, Panizza S, Nikraz H (2017) Effect of powdered recycled tire on sulfate resistance of cemented clay. Journal of Materials in Civil Engineering 29(10).

9. Keramatikerman M (2018) Investigations into Effect of by product Binders in Improvement of Cyclic Behaviour of Soil. Australia.

10. Keramatikerman M, Chegenizadeh A, Nikraz H, Sabbar AS (2018a) Effect of flyash on liquefaction behaviour of sand-bentonite mixture. Soils and foundations 58(5): 1288-1296.

11. Keramatikerman M, Chegenizadeh, A, Nikraz H (2018b) Shear strength characteristics of over-consolidated clay treated with GGBFS. Australian Geomechanics Journal 53(2): 141-149.

12. Keramatikerman M, Chegenizadeh A, Nikraz H (2017) An investigation into effect of sawdust treatment on permeability and compressibility of soil bentonite slurry cut-off wall. Journal of Cleaner Production 162(20): $1-6$

13. Pelisser F, Barcelos A, Santos D, Peterson M, Bernardin AM (2012) Lightweight concrete production with low Portland cement consumption. Journal of Cleaner Production 23(1): 68-74.

14. Olgun M (2013) Effects of polypropylene fiber inclusion on the strength and volume change characteristics of cement fly ash stabilized clay soil. Geosynthetics International 20(4): 263-275.

15. Galán Marín C, Rivera Gómez C, Petric J (2010) Clay-based composite stabilized with natural polymer and fibre. Construction and Building Materials 24(8): 1462-1468.

16. Cokca E, Yazici V, Ozaydin V (2009) Stabilization of expansive clays using granulated blast furnace slag (GBFS) and GBFS-cement. Geotechnical and geological engineering 27(4): 489.

17. Yi Y, Zheng X, Liu S, Al Tabbaa A (2015) Comparison of reactive magnesia and carbide slag activated ground granulated blastfurnace slag and Portland cement for stabilisation of a natural soil. Applied Clay Science 111: 21-26.

18. Kukko H (2000) Stabilization of clay with inorganic by-products. Journal of materials in civil engineering 12(4): 307-309.

19. Cabalas AF, Karabash Z, Mustafa WS (2014) Stabilising a clay using tyre buffings and lime. Road materials and pavement design 15(4): 872-891.

20. Shibi T, Kamei T (2014) Effect of freeze thaw cycles on the strength and physical properties of cement stabilised soil containing recycled bassanite and coal ash. Cold regions science and technology (106-107): 36-45.

21. Fatahi B, Khabbaz H (2012) Mechanical characteristics of soft clay treated with fibre and cement. Geosynthetics International 19(3): 252262.

22. Chan CM (2011) Effect of natural fibres inclusion in clay bricks: Physico mechanical properties. International Journal of Civil and Environmental Engineering 5(1): 7-13.

23. Fernández Pereira C, De La Casa JA, Gómez Barea A, Arroy F, Leiva C, et al. (2011) Application of biomass gasification fly ash for brick manufacturing. Fuel 90(1): 220-232.

24. Nonracist P, Jumlongrach N, Youwai S, Chucheepsakul S (2010) Influence of fly ash on unconfined compressive strength of cement-admixed clay at high water content. Journal of Materials in Civil Engineering 22(1): 49-58. 